INTERNATIONAL JOURNAL OF RESEARCHES IN BIOSCIENCES, AGRICULTURE AND TECHNOLOGY (C) VISHWASHANTI MULTIPURPOSE SOCIETY (Global Peace Multipurpose Society) R. No. MH-659/13(N) www.ijrbat.in

\title{
THE EFFECT OF MECHANICAL AND CHEMICAL SCARIFICATION ON GERMINATION OF ARHAR SEEDS.
}

\author{
Rajesh Gadewar 1, Sanjiv Charjan 2, Mohan Patil 3. Ashish Lambat 4 \\ 1,4 Assistant Professor, Sevadal Mahila Mahavidyalaya and Research Academy, Nagpur (MS) \\ ${ }^{2,3}$ Assistant Professor, College of Agriculture (Dr. PDKV's) Nagpur. \\ Corresponding Author Email : lambatashish@gmail.com
}

\begin{abstract}
:
Five genotypes Arhar were sown during 2014. The seeds after harvesting, threshing and processing were evaluated for their hardseededness dormancy. The findings of the present study indicate that concentrated sulphuric acid, hot water, sand scarification and hot air oven methods are effective for reducing hardseededness in Arhar. All the above mentioned treatments showed injuries effect to the seed embryo by increasing the dead seeds and abnormal seedlings except concentrated sulphuric acid treatment. In general concentrated sulphuric acid treatment for 60 seconds have been found most effective for breaking seeds coat dormancy and also significantly highest germination percentage compared to the above mentioned treatments under taken in the present investigation.
\end{abstract}

Key words :- Arhar, dormancy, hard seed coat, germination.

\section{INTRODUCTION.}

Seeds dormancy is defined as the state in which seeds are prevented from germination even under favorable conditions for germination. The impermeability of seed coat to water is typical example of exogenbility are known as hard seeds. This impermeability may be due to the presence of a cuticle and a well developed layer of palisade cells or both. Cutin deposits have been reported by Thronton (1968). The development of hard seeds has been reported to be influenced both by genotypic and environmental factors (Puri and Laudlaw, 1984)

Most of the legume crop plants produce hard seeds to varying percentages. Most workers have found this trait to be highly heritable. However, the available literature does not clearly state the developmental stage in which the seed develops into hard seed. Hardseededness in Arhar creates problems in testing for germinability under laboratory conditions. Due to this state of affair there is great problem under field condition in securing uniform germination and good crop stand for maximum crop production. The present study was undertaken to evaluate the methods to overcome hardseededness in Arhar.

\section{MATERIALS AND METHODS.}

Five genotypes of Arhar viz. C-11, NO. 148, BDN - 2 Maroti and TAT-10 were used in the various phases of this study, produced in Kharif, 2014. Hard seeds which did not imbibe water were sorted out from the normal seeds which imbibe water. To evolve a quick method for breaking hardseededness in five genotypes of Arhar, the hard seeds were subjected to concentrated sulphuric acid (for 30 and 60 seconds), hot water $\left(100^{\circ} \mathrm{C}\right.$ for 120 and 180 seconds), sand scarification $\left(100^{\circ} \mathrm{C}\right.$ for 240 and 480 seconds) and air oven $\left(140^{\circ} \mathrm{C}\right.$ for 15 and 30 seconds)

For germination test in laboratory, the germination medium used was rolled towels paper under controlled conditions (i.e. temperature at $25 \pm 2{ }^{\circ} \mathrm{C}$ constant and relative humidity $85 \%$ ), For acid treatment, seeds were soaked in concentrated sulphuric acid for the specified duration with constant stirrings (Dharmalingam et al. 1973), Seeds were thoroughly washed in running water after the acid treatment and the germination was tested in quadruplicate with 100 seeds in each replication. The germination count was taken on the $8^{\text {th }}$ day and germination percentage was recorded on the basis of normal seedlings (ISTA,1985) 


\section{RESULTS AND DISCUSSION}

Arhar tested for different methods of breaking the hardseededness are presented in Table 1. The overall comparisons of mean among and within genotypes and treatments for both normal seedling and hard seed percentage showed that concentrated suphuric acid for 60 seconds was the most effective treatment for reducing hard seeds content. It was followed by hot water for 180 seconds sand scarification for 480 seconds hot water 120 seconds, hot air oven 30 seconds, sand scarification 240 seconds, concentrated sulphuric acid of 30 seconds and hot air over 15 seconds. All the treatments showed injurious effect by increasing the abnormal seedling except concentrated sulphuric acid for 60 seconds. There is no germination in control (untreated ) seeds Duran and Tortosa (1985) has clearly explained the effect of concentrated sulphuric acid on seed coat of Sinapsis aruensis and conclude that it was the rapid dessiciation produced by concentrated sulphuric acid and not its hydrolytic capacity which seems to cause fragmentation of integuments and thus allowing the passage of water to the embryo. A similar mode of action can also be proposed for the shown as Arhar genotypes to the treatment with sulphuric acid.

\section{CONCLUSIONS}

The results obtained in the present investigation indicate that concentrated sulphuric acid treatment for 60 second has been found more effective for breaking hard seed coat dormancy in Arhar. The result confirms the finding of Charjan and Tarar (1990), Sing and Tomer (1993) and Cherian et al. (2011).

Effectiveness of concentrated sulphuric acid, hot water and hot air oven treatment for breaking hardseededness was also reported in related crops by Borikar et al. (1985), Radhakrishnan et al. (1989), Rana and Nautiyal. (1989), Tomer and Maguire. (1989), Verma and Singh. (1989), Charjan and Tarar. (1991), Singh and Tomer. (1993) and Cherian et al. (2011).

\section{REFERENCES}

Borikar, S.T., Singh, A. R. and Katkade, J. L. 1985. Effect of pretreatment of greegram (Vigna radiate) seed with certain chemicals on its germination, seed Res. 13(1) : 192-194.

Charjan, S.K.U. and Tarar, J.L. 1990. Methods to overcome hardseededness in soybean (Glycine $\max$ L. ) New Agriculturist 1(1) : 71-74.

K. Cherian, A. Lambat, R.Gadwar, P. Bhandari, S. Charjan, P.Lambat. 2011. Post harvest dormany in Pigeon pea and their mthods to overcome, In : Proceeding of the International Conference in Agricultural Engineering. Chonburi, Thailand C-45.

Dharmalingam, C. , Madhavrao, S. and Sundararaj, D. 1973 Pregermination treatment of testing seeds (Tephrosia purpures Pers.) to improve germination. Seeds Research. 1:58-62.

Duran. J.M. and Tortosa, M.E. 1985. The effect of mechanical and chemical scarification on germination of charlock (Sinapsis arvensis L. ) seeds, Seeds Science and Technology. 13: 155-163.

ISTA. 1985. International rules for seeds testing. Seed Sci. and Technol. 13: 299513

Puri, K.P. and Laudlow, A.S. 1984. The effect of temperature on components of seed yield and seed quality of hard red winter wheat from production field. J. App. Seed Production. 2: 18-23.

Radhakrishnana, J., Mahadevoppa, M. Joshi S. and Prasad, T.G. 1989. Dormancy studies in Cassia sericae seeds, Seeds Research. 17 (2) : 118-121

Rana. U., and Jautiyal, A.R. 1989. Coat imposed dormancy in Acacia famesiana seeds. Seeds Research. 17 (2) : 122.

Singh, KJ. And Tomer, R.P.S. 1993. Studies on hard seeds in black - gram (Vigna mumgo (L). Heper, Seeds Research. Special Vol. 2 : 919 : 923.

Thornton, M.L, 1968. Seed dormancy in water melon. Proceedings Association official Seed Analysts. 58: 80-84. 
Tomer, RPS. And Magurie, J.D. 1989. Hard seed studies in alfalfa. Seeds Research. 17 (1) : 29-31.
Verma, O.P. and Singh, P.V. 1989. Methods to overcome hardseededness in Pigeon pea. Seeds Research. 17 (2) : 197-198

Table 1 Effect of different treatments on Germinability of Arhar

\begin{tabular}{|c|c|c|c|c|c|c|c|c|c|c|c|c|c|c|c|c|}
\hline \multirow[t]{2}{*}{ S.N } & \multirow[t]{2}{*}{ Treatments } & \multicolumn{3}{|c|}{$\mathrm{T}-9$} & \multicolumn{3}{|c|}{ TAU-1 } & \multicolumn{3}{|c|}{ TAU-2 } & \multicolumn{3}{|c|}{ TPU-4 } & \multicolumn{3}{|c|}{ PKV-Udid-15 } \\
\hline & & $\mathrm{N}$ & $A b$ & $\mathrm{H}$ & $\mathrm{N}$ & $A b$ & $\mathrm{H}$ & $\mathrm{N}$ & $A b$ & $\mathrm{H}$ & $\mathrm{N}$ & $A b$ & $\mathrm{H}$ & $\mathrm{N}$ & $A b$ & $\mathrm{H}$ \\
\hline 1 & $\begin{array}{l}\text { Control (Untreated } \\
\text { hard seeds) }\end{array}$ & 0 & 0 & 100 & 0 & 0 & 100 & 0 & 0 & 100 & 0 & 0 & 100 & 0 & 0 & 10 \\
\hline \multirow[t]{3}{*}{2} & $\begin{array}{l}\text { Concentrated } \\
\text { sulphuric acid }\end{array}$ & & & & & & & & & & & & & & & \\
\hline & (i) 30 seconds & 80 & 24 & 16 & 88 & 3 & 9 & 80 & 9 & 11 & 80 & 6 & 14 & 83 & 6 & 11 \\
\hline & (ii) 60 seconds & 92 & 4 & 4 & 95 & 4 & 1 & 90 & 10 & 0 & 95 & 4 & 1 & 91 & 6 & 3 \\
\hline \multirow[t]{3}{*}{3} & $\begin{array}{l}\text { Hot water treatment } \\
\left(100^{\circ} \mathrm{C}\right)\end{array}$ & & & & & & & & & & & & & & & \\
\hline & (i) 120 seconds & 81 & 4 & 15 & 81 & 3 & 16 & 78 & 13 & 9 & 78 & 2 & 20 & 80 & 3 & 17 \\
\hline & (ii) 180 seconds & 89 & 6 & 5 & 91 & 4 & 5 & 85 & 5 & 510 & 92 & 4 & 4 & 90 & 5 & 5 \\
\hline \multirow[t]{3}{*}{4} & $\begin{array}{l}\text { Sand Scarification } \\
\left(100^{\circ} \mathrm{C}\right)\end{array}$ & & & & & & & & & & & & & & & \\
\hline & (i) 240 seconds & 75 & 5 & 20 & 78 & 5 & 17 & 74 & 12 & 14 & 70 & 3 & 27 & 76 & 6 & 18 \\
\hline & (ii) 480 seconds & 85 & 5 & 10 & 90 & 4 & 6 & 86 & 10 & 4 & 90 & 5 & 5 & 88 & 3 & 9 \\
\hline \multirow{3}{*}{5} & Hot air oven $\left(140^{\circ} \mathrm{C}\right)$ & & & & & & & & & & & & & & & \\
\hline & (i) 15 seconds & 84 & 7 & 9 & 75 & 5 & 20 & 68 & 14 & 18 & 75 & 4 & 21 & 70 & 5 & 25 \\
\hline & (ii) 30 seconds & 82 & 6 & 8 & 87 & 7 & 6 & 80 & 14 & 6 & 87 & 3 & 10 & 86 & 4 & 10 \\
\hline
\end{tabular}

